
\title{
28 Resarch Square \\ EBSD Study on Proeutectoid Ferrite and Eutectoid Ferrite Refinement Mechanism of D2 Wheel Steel Under a Rolling Condition
}

Jun Hua

Dalian Jiaotong University

Pengtao Liu

Dalian Jiaotong University

Xiujuan Zhao

Dalian Jiaotong University

Chong Su

Dalian Jiaotong University

Ruiming Ren ( $\nabla$ rmren@djtu.edu.cn )

Dalian Jiaotong University

\section{Research Article}

Keywords: D2 wheel steel, EBSD, Proeutectoid ferrite, Eutectoid ferrite, Shear strain.

Posted Date: April 29th, 2021

DOI: https://doi.org/10.21203/rs.3.rs-459242/v1

License: (c) (1) This work is licensed under a Creative Commons Attribution 4.0 International License. Read Full License

Version of Record: A version of this preprint was published at Tribology Letters on October 11th, 2021. See the published version at https://doi.org/10.1007/s11249-021-01527-6. 


\section{Abstract}

In this paper, the SEM (with EBSD system) is used to study the refinement mechanism of proeutectoid ferrite (Pro-f) and eutectoid ferrite (Eut-f) of D2 wheel steel in a rolling contact. The results indicate that with the increase of the shear strain $(y<0.21)$, the dislocation density in the proeutectoid ferrite increased continuously, and the dislocation cells formed were uniformly distributed in the grains. Subsequently, the dislocation cell boundaries were changed into low-angle boundaries (LABs), and then the low-angle boundaries were gradually changed into the high-angle boundaries (HABs), and the average grain size was refined from the original $8 \mu \mathrm{m}$ to $710 \mathrm{~nm}$. When the shear strain is at $0.21 \leq \gamma \leq 0.84$, dislocation piled up occurred at the ferrite side of the interface of eutectoid ferrite/cementite, and the spatial misorientation between adjacent two eutectoid ferrites increased gradually, then the ferrite lamellar is divided into bamboo-like by the low-angle boundaries, and proeutectoid ferrite the grains are gradually refined into equiaxed grain. When the shear strain is at $0.84<y<3.314$, the number of high-angle boundaries inside the eutectoid ferrite lamellar increased, and it is refined into bamboo-like grains. The two kinds of ferrite grains are repeatedly refined many times by the equiaxial grains "elongation- bamboo like refinement-elongation", which gradually reduced the size difference. As the shear strain further increases, the two kinds of ferrite are completely mixed into the same morphology, the dislocation density is dramatically reduced, and ultra-fine equiaxed grains about $110 \mathrm{~nm}$ is formed.

\section{Introduction}

With the rapid development of high-speed railways, friction and wear between wheels and rails and rolling contact fatigue damage are becoming more and more serious ${ }^{[1-3]}$. Such as the white layer will accelerate the peeling of the material ${ }^{[4]}$, and the wheel polygonisation wear will increase the vibration of the train ${ }^{[5]}$.Those problems shorten the repair and maintenance cycle of wheels and rails, and increase railway operating costs ${ }^{[6,7]}$. Therefore, higher requirements are put forward for the service performance of wheel rail materials.

During the operation of the train, the wheel-rail material in the contact surface layer will not only turn into a phase transformation white layer due to the frictional heating exceeding the austenitizing temperature of the stee ${ }^{[8]}$, but also produce obvious plastic deformation under the combined action of normal stress and frictional stress. Obviously, the plastic deformation process will also cause continuous changes of the surface microstructure and properties. The microstructure evolution of pearlite steel under different conditions has been studied by many scholars at home and abroad. Pan et al. studied the detailed changes of microstructure in the wear process of CL65 pearlite wheel steel through sliding wear test, and finally formed $35 \mathrm{~nm}$ nanocrystalline on the wearing surface, and the surface nanocrystalline formation was mainly completed through four stages of transformation ${ }^{[9]}$. Through the observation of the changes of cementite, Languillaume et al. believe that when the cementite sheet becomes thinner, the energy of the system increases, and in order to reduce the energy, the cementite finally dissolves into the ferrite grain ${ }^{[10]}$. However, Gridnev and Gavriljuk et al. believe that the decomposition of cementite was due to the 
fact that the binding energy between carbon atoms and the dislocation in ferrite was much higher than that between the lattice of cementite and carbon atoms under the action of shear strain, and the carbon

atoms and the dislocation form the Cottrell atmosphere ${ }^{[11,12]}$. Chen et al. conducted a rolling-sliding wear test on pearlite steel, found that a white layer with a certain thickness was formed on the surface of the sample, the white layer was nanocrystalline a-Fe-C alloy ${ }^{[13]}$. Linz et al. studied the R260 rail steel after wear and found that at a depth of $3 \mathrm{~mm}$ from the surface, the pearlite colony was severely fragmented under the effect of the accumulation of shear strain. On the surface of the rail, the original pearlite colony was elongated into a layered structure in the shear direction ${ }^{[14]}$. Hua and co-authors applied EBSD technique to preliminary analyze the changes of proeutectoid ferrite at different depths of crest and trough after polygonisation wear in the rolling wear conditions, and found that the surface layer ferrite grains were obviously refined ${ }^{[15]}$.

Most of the currently used wheel and rail steels belong to the middle and high carbon hypoeutectoid steel. There are two kinds of ferrite microstructures: proeutectoid and eutectoid, but the evolution process of the two during wear and plastic deformation is different. It also makes the microstructure evolution of the entire deformation layer more complicated. Therefore, it is necessary to conduct a comparative study on the evolution process of the proeutectoid ferrite and eutectoid ferrite under the same wear and plastic deformation conditions.

\section{Experimental Details}

\subsection{Experimental materials and methods}

The experiment was carried out on a double-disc rolling wear test machine, the contact mode and size diagram of the sample as shown in Fig. 1. The main sample was D2 wheel steel, and the original microstructure was proeutectoid ferrite (36\%) and pearlite (64\%). The controlled sample was U71 Mn rail steel, and the original microstructure was pearlite. The main chemical composition and hardness of the main/controlled samples are shown in Table 1.

In this experiment, the maximum contact stress of main/controlled sample was $1240 \mathrm{MPa}$, the rotational speed of the sample was $1440 \mathrm{r} / \mathrm{min}$, and the number of cycles were $2 \times 10^{5}$. The experiment was carried out in dry conditions at room temperature. In order to reduce the influence of the wear debris and friction heat during the wear process, air-cooling condition was used. Leica DMi8 optic microscope (OM) was adopted to observe the cross-sectional microstructure. The SUPRA55 field emission scanning electron microscopy (SEM) and its EBSD system were used to characterize the changes of the microstructure. The surface microstructure also was observed and analyzed by JEM-2100F electron microscope. 
Table 1

The main chemical composition and hardness of the material

\begin{tabular}{|lllllll|}
\hline Material & \multicolumn{2}{l}{ Main chemical composition (wt\%) } & Hardness/HV \\
\cline { 2 - 6 } & C & Si & Mn & S & P & \\
\hline D2 & $0.50-0.56$ & $0.90-1.10$ & $0.90-1.10$ & $\leq 0.01$ & $\leq 0.015$ & 296 \\
\hline U71Mn & $0.65-0.77$ & $0.15-0.35$ & $1.00-1.40$ & $\leq 0.03$ & $\leq 0.03$ & 330 \\
\hline
\end{tabular}

\subsection{Microstructure characterization}

All SEM and EBSD samples were cut into $6 \mathrm{~mm} \times 6 \mathrm{~mm} \times 3 \mathrm{~mm}$ along the rolling direction, ground with 3000 grit sandpaper and mechanically polished. These cross-sections samples were prepared in the way that silica sol suspension was used to conduct mechanical polishing and chemical corrosion ${ }^{[16]}$. The advantage of this method was that the difference in contrast under SEM can be used to qualitatively identify the grain misorientation. The EBSD samples were polished using GATAN Ilion II 697 argon ion polishing system, the voltage was $5 \mathrm{kV}$, and the polishing time was $2 \mathrm{~h}$. The size of cementite was too thin to be resolved by EBSD system ${ }^{[17]}$, therefore, only the proeutectoid ferrite (Pro-F) and eutectoid ferrite (Eut-F) at different distances from surface were analyzed. The acceleration voltage was $20 \mathrm{kV}$, the working distance (WD) was $14 \mathrm{~mm}-16 \mathrm{~mm}$, and the sample table tilt was $70^{\circ}$. The step size was $80 \mathrm{~nm}$ in the original microstructure and $50 \mathrm{~nm}$ in other regions.

HKL Channel 5 was used to post-process the EBSD results. Among them, Euler angle maps were used to characterize the change of grain misorientation. Grain boundary distribution maps indicate the number of grain boundary with different angles. Local Misorientation (LocMis) maps qualitatively reflect the degree of homogeneity of plastic deformation or the defect density. For the sake of argument, the misorientation in $2-10^{\circ}$ was the low-angle boundary, and greater than $10^{\circ}$ was the high-angle boundary.

TEM samples were cut a $3 \mathrm{~mm}$ diameter semi-cylinder on the sample section, and used a low-speed saw to cut a $0.8 \mathrm{~mm}$ thickness semicircle, and then ground them to a 30-40 $\mu \mathrm{m}$ thickness with different types of grit sandpapers, and finally used Model 691 Precision Ion Polishing System with single ion beam model to thin these samples.

\section{Results}

\subsection{Determination of shear strain}

After $2 \times 10^{5}$ cycles, obvious plastic deformation layer occurred on the cross-sectional microstructure (Fig. 2(a)). According to the previous investigations ${ }^{[18]}$, an exponential dependence of displacement (y) on distance from the surface $(\mathrm{x})$ was firstly evaluated, and the following relationship was satisfied: 


$$
y(x)=y_{s} \exp (-k x)
$$

Where, $y_{s}$ is the displacement of the outermost surface $(x=0)$ of the sample, and $k$ is a constant, which can be determined by the experimental data, in this study, $y_{s}=3.409$ and $k=0.014$. As a result, Eq. (1) changes into:

$$
y(x)=3.409 \exp (-0.014 x)
$$

The shear strain $y(x)$ can be obtained by the first order partial differential of $\mathrm{y}$ to $\mathrm{x}$,:

$$
\gamma(x)=-\frac{\partial y(x)}{\partial x}=0.048 \exp (-0.014 x)
$$

Therefore, the relationship between the shear strain and the distance from the surface is shown in Fig. 2 . The shear strain reaches maximum on the surface, and decreases with the increase of the distance from the surface.

\subsection{Evolution of proeutectoid and eutectoid ferrite \\ 3.2.1 The original microstructure}

The SEM image as shown in Fig. 3(a). The original microstructure of D2 wheel steel was lamellar pearlite and massive proeutectoid ferrite (Pro-F), and the grain size of the proeutectoid ferrite was about $8 \mu \mathrm{m}$ and the pearlite interlamellar spacing was about $150 \mathrm{~nm}$. The pearlite colony boundary, the pearlite colony and the proeutectoid ferrite interface, and the proeutectoid ferrite grains were all high-angle boundaries (HABs) (Fig. 3(b), Fig. 3(c)), thence the proportion of HABs in the original microstructure was the largest, accounting for $96 \%$, and mainly distributed at $30-62^{\circ}$. It could also be seen that there were a small number of low-angle boundaries (LABs) (Fig. 3(d)), therefore, there were a certain number of the lowangle boundaries or sub-grain boundaries.

\subsubsection{Evolution of proeutectoid ferrite and eutectoid ferrite}

Figure 4 showed the microstructure at $400 \mu \mathrm{m}-200 \mu \mathrm{m}(\gamma=0.012-0.21)$ from the surface. The comparison of the original microstructure showed that the pearlite was basically unchanged (Fig. 3), while the contrast of proeutectoid ferrite was significantly changed (Fig. 4(a), Fig. 4(b), Fig. 4(c)). At $400 \mu \mathrm{m}$ from the surface $(\gamma=0.012)$, some of the sub-grain in the proeutectoid ferrite began to change to the LABs (Fig. $\left.4\left(a_{1}\right), 4\left(a_{2}\right)\right)$. At $300 \mu \mathrm{m}(\mathrm{Y}=0.051)$, the number of LABs in the proeutectoid ferrite increased significantly, and a small amount of $L A B s$ changed to HABs, but there was no obvious change in the eutectoid ferrite (Fig. $4\left(b_{1}\right)$, Fig. $4\left(b_{2}\right)$ ). When the distance from the surface was $200 \mu \mathrm{m}(\mathrm{Y}=0.051)$, the 
number of LABs changed to HABs in the proeutectoid ferrite gradually increased (Fig. 4( $\left.\mathrm{C}_{1}\right)$, Fig. $4\left(\mathrm{C}_{2}\right)$ ), forming different shape grains with an average size of $710 \mathrm{~nm}$. The misorientation between some eutectoid ferrite lamellars reached $2 \sim 10^{\circ}\left(\right.$ Fig. $4\left(c_{2}\right)$ ).

The microstructure at $100 \mu \mathrm{m}(\gamma=0.84)$ from the surface as shown in Fig. 5. In the proeutectoid ferrite, the number of LABs changed to HABs increased significantly (Fig. 5(c)), and the grains were further refined, forming smaller equiaxial grains with an average size of $550 \mathrm{~nm}$. Although the microstructure of pearlite colony did not change significantly under SEM, the contrast difference was more and more obvious, indicating that the spatial misorientation of eutectoid ferrite changed significantly (Fig. 5(a)). The number of eutectoid ferrite lamellar with low-angles misorientation also increased gradually, and even a few changed to high-angle misorientation (Fig. 5(c)). Meanwhile, a low-angle boundary was formed inside the eutectoid ferrite lamellar, and then began to be divided into bamboo-like (Fig. 5(a)-(c), 1).

Figure 6 showed the microstructure at $50 \mu \mathrm{m}(\mathrm{\gamma}=1.692)$ from the surface. The pearlite colony has undergone obvious plastic deformation, cementite suffered significant bending, and the interlamellar spacing decreased significantly (Fig. 6(a) and 6(b)). The proeutectoid ferrite grains after refining had an average size of $428 \mathrm{~nm}$, and some of which were obviously deformed to form bamboo-like grains (Fig. 6(d), A), and the number of HABs further increased (Fig. 6(c), Fig. 6(d)). The number of high-angle between eutectoid ferrite lamellars increased markedly, and the number of LABs changed to HABs inside the eutectoid ferrite lamellar also increased remarkably, resulting in the formation of bamboo-like grains, and the eutectoid ferrite was further divided and refined (Fig. 6(d), B).

Figure 7 showed the microstructure within $15-0 \mu \mathrm{m}(2.763 \leq \mathrm{\gamma}<3.45)$. Figure 8 showed the grain size changes of two kinds of ferrite at different distances from the surface. It was known from Fig. 7(a) that within 15-2 $\mu \mathrm{m}$, the plastic deformation and refinement of the surface microstructure were becoming more and more severe. The lamellar pearlite has lost its original lamellar characteristics, cementite was severely fragmented, and its size was dramatically reduced, and the fine carbides existed in the form of particles at the ferrite boundaries. Therefore, according to the distribution of cementite particles, the areas of proeutectoid ferrite and eutectoid ferrite could still be distinguished under SEM. Within $2-0 \mu \mathrm{m}$ (3.314 $\leq y<3.45$ ), the two kinds of ferrite continued to be refined and the carbides were largely dissolved, and the entire microstructure became fibrous parallel to the surface, thence the difference between the two could not be resolved under the SEM.

As could be seen from the EBSD analysis results, within $15-2 \mu \mathrm{m}(2.763 \leq \gamma<3.314)$, proeutectoid ferrite and eutectoid ferrite grains continued to be divided and refined, and the number of HABs increased significantly, and fine bamboo-like grains were formed continuously (Fig. 7(b)-(c)). According to Fig. 8, the average grain size of the two measured at $11 \mu \mathrm{m}(\mathrm{Y}=2.763)$ was $365 \mathrm{~nm}$ and $270 \mathrm{~nm}, 287 \mathrm{~nm}$ and 195 $\mathrm{nm}$ at $8 \mu \mathrm{m}(\mathrm{\gamma}=3.047), 190 \mathrm{~nm}$ and $153 \mathrm{~nm}$ at $4 \mu \mathrm{m}(\mathrm{\gamma}=3.223)$, and the difference between the two gradually narrowed. However, within $2-0 \mu \mathrm{m}(3.223<\gamma \leq 3.409)$, the ultrafine grains of about $110 \mathrm{~nm}$ were formed. It should be noted that due to the analytical capability of EBSD, the information of the most 
superficial finer grains is limited (Fig. 7(b), Fig. 7(c)), thence the actual average grain size should be less than the measured $110 \mathrm{~nm}$ (Fig. 9(d)).

According to TEM analysis, it could be seen from the bright field that the size of some grains was less than $100 \mathrm{~nm}$ (Fig. 9 (a)), and selected-are electron diffraction of ferrite was basically ring (Fig. 9 (b)), which also indicated that nanocrystalline was formed on the surface. This was basically consistent with the EBSD results.

The results of comprehensive statistics on the relative amounts of proeutectoid ferrite and eutectoid ferrite low-angle boundaries and high-angle boundaries at different distances from the surface as shown in Fig. 10. At $400 \mu \mathrm{m}(\mathrm{Y}=0.012)$, the shear strain was relatively small, and the boundaries were mainly dominated by LABs, however, the HABs distribution were basically the same as the original microstructure, mainly distributed at $30-62^{\circ}(\mathrm{Fig} .10(\mathrm{a}))$. At $300 \mu \mathrm{m}(\mathrm{Y}=0.051)$, the number of LABs formed increased significantly, resulting in a significant increase in the proportion of LABs (Fig. 10(b)). With the decrease of the distance from the surface, the shear strain gradually increased, and the LABs gradually changed to the HABs, leading to the proportion of LABs decreased while the proportion of HABs increased significantly, and it was mainly distributed between $10-56^{\circ}$ (Fig. 10 (c)-(f)).

\section{Discussion}

\subsection{Dislocation density evolution under different distances}

A large number of studies on grain refinement caused by plastic deformation have shown that, for ferrite in steel, its main refinement mechanism formed sub-grains through dislocation multiplication entanglement, and dislocation reaction. In the further dislocation multiplication, the sub-grains were changed to the low-angle boundaries and even the high-angle boundaries ${ }^{[13,21]}$. The kernel average misorientation (KAM) method ${ }^{[22]}$ was adopted to determine the local misorientation by the EBSD orientation data. Local crystal orientations at different distances from the surface were measured to study the dislocation density evolution. The local misorientation at a pixel point was determined by the 24 surrounding pixel points (filter size is $5 \times 5$ ):

$$
\Delta \theta_{i}=\frac{1}{n} \sum_{j=1}^{n}\left|\theta_{j}^{s u r}-\theta_{i}\right|
$$

where $\theta_{i}$ represents the local misorientation at the point ' $"$ ' and is the misorientation at its neighboring point's.

The dislocation density can be calculated by the following formula: 


$$
\rho^{G N D}=\frac{\alpha \Delta \theta_{i}}{\mu \mathrm{b}}
$$

Where, $a$ is a constant, usually $a=3$ in mixed dislocations ${ }^{[23]}, \mu$ is the step size of the EBSD map, $b$ is the Berber vector.

The local misorientation distribution maps and dislocation density calculation results at different distances as shown in Fig. 11 and Fig. 12. There were a certain number of dislocations in both types of ferrite in the original microstructure (Fig. 11(a)). Under small shear strain, the dislocations in the original microstructure were prone to movement and activated other dislocations, resulting in a large number of dislocations in the proeutectoid ferrite, and the change of the local misorientation mainly occur in the proeutectoid ferrite (Fig. 11(b)), thence the dislocation density increased significantly at $400 \mu \mathrm{m}(\mathrm{Y}=$ 0.012) (Fig. 12). With the increase of shear strain, the dislocations in the two kinds of ferrite accumulated continuously and the distribution of misorientation increased (Fig. 11(c)). The number of HABs in the proeutectoid ferrite has slightly increased (Fig. 7(c)), and the misorientation was slightly reduced, however, the misorientation in the eutectoid ferrite has increased significantly (Fig. 11(d)), thence the dislocation density increased rapidly at $400-200 \mu \mathrm{m}(\gamma=0.051-0.21)$ (Fig. 12). As the shear strain continued to increase, and the number of proeutectoid ferrite grains changing from LABs to HABs increased significantly, and dislocations multiplication also formed in the refined grains. At the same time, misorientation in eutectoid ferrite increased slightly (Fig. 11(e)), the proportion of LABs decreased (Fig. 10(b) and Fig. 10(c)), resulting in the slow increase of dislocation density within $200-50 \mu \mathrm{m}(\mathrm{Y}=$ 0.21-1.692) (Fig. 12). When approaching the surface, the grains in the proeutectoid ferrite were basically changed to HABs, and the misorientation decreased to the minimum value within $11-8 \mu \mathrm{m}(\mathrm{y}=2.922-$ 3.047) from the surface (Fig. 11(f)), according to Eqs. (4) and (5), the dislocation density was $6.15 b^{-}$ ${ }^{1} \times 10^{12} \mathrm{~m}^{-2}$, and the dislocation density decreased rapidly. Moreover, the number of eutectoid ferrite grains changed to HABs also increased significantly, resulting in a significant decrease in the dislocation density near the surface (Fig. 12).

\subsection{Refinement mechanism of proeutectoid ferrite and eutectoid ferrite}

Microstructure evolution diagram of proeutectoid ferrite and eutectoid ferrite as shown in Fig. 13. Previous studies have shown that strain plays an important role in grain refinement during plastic deformation ${ }^{[24,25]}$. Under a small shear strain (lower than the shear strain of pearlite deformation) (Fig. 13(b)), when the stress reached the critical shear stress of the dislocation movement, the dislocation in the proeutectoid ferrite began to move (Fig. 13(a)), and simultaneously the moving dislocations also stimulated the generation of new dislocations. A large number of dislocations accumulated rapidly, and the interaction between the dislocations leaded to dislocation entanglement, forming dislocation cells or 
dislocation walls, which were relatively uniformly distributed in the proeutectoid ferrite grains. Dislocation in the dislocation cells or dislocation walls was annihilated and rearranged, forming the sub-grain. In order to reduce the free energy in the proeutectoid ferrite, the dislocations on the sub-grain boundary was further rearranged to form a low-energy structure, which changed into a low-angle boundary (Fig. 10(a)), and the proeutectoid ferrite started to be divided and refined.

When the shear strain increased to 0.051 (Fig. 13(c)), the slip system with more dislocations was activated, and high-density dislocations were continuously formed in the proeutectoid ferrite (Fig. 11(b)). The number of $L A B s$ increased obviously due to the absorption of the dislocation by dislocation cells within the grain (Fig. 4(f)). The shear strain caused the misorientation between the adjacent LABs to increase gradually, and finally changed into HABs. When the shear strain was at $0.21 \leq Y \leq 2.763$ (Fig. 13(d-g)), the misorientation between adjacent grains continued to increase, resulting in a significant increase in the proportion of HABs. Refinement grain also continued to refine the proeutectoid ferrite grains by the above mechanism. Therefore, with the increase of shear strain, the number of HABs in the proeutectoid ferrite grains increased (Fig. 4-Fig. 6), and the proportion of HABs between $10-62^{\circ}$ gradually increased (Fig. 10(b-c)), local misorientation value gradually decreased (Fig. 12(c-e)), and the dislocation density decreased.

Due to the difference in strength between pearlite and proeutectoid ferrite, there were some differences in the refinement process and mechanism of the two kinds of ferrite. The cementite structure in pearlite was a covalent bond, with high hardness and brittleness ${ }^{[26]}$, which was not easy to produce plastic deformation and played a supporting role for eutectoid ferrite. Therefore, the plastic deformation of pearlite first occurred in eutectoid ferrite. Generally, the interface has four main functions in the process of plastic deformation ${ }^{[27]}$, (1) as a source of defects; (2) absorption and annihilation of defects; (3) storage of defects; (4) barriers to dislocation movement. The eutectoid ferrite/cementite interface also played a vital role in the process of dislocation nucleation, development and annihilation. With the increase of shear strain (Fig. 13(c-d)), the stress has not reached the point of the bending deformation of cementite, and the interlamellar spacing has not been changed. When the dislocations generated inside the eutectoid ferrite lamellar move to the eutectoid ferrite/cementite interface, they were easily captured by the interface and dislocation pile-up were produced. When the dislocation was piled up to a certain degree, a greater stress concentration was generated, which promoted the nucleation of a large number of dislocations at the interface, and dislocation entanglements were generated at the interface to form dislocation cells or dislocation walls. Moreover, the larger the shear strain was, the greater the number was. The formation of dislocation cells or dislocation walls in a small volume changed the local crystal orientation of the ferrite lamellar ${ }^{[28]}$, therefore, the LocMis value could be found to be very high at the eutectoid ferrite interface (Fig. 11(b), Fig. 11(c)).

The deformation of a single eutectoid ferrite lamellar was not uniform, and the dislocations also were not evenly distributed in the eutectoid ferrite lamellar. Therefore, in the direction parallel to ferrite lamellar, the misorientation of the adjacent two eutectoid ferrite at partial positions of the interface were changed to a low-angle misorientation through the annihilation and rearrangement of dislocations. The residual stress 
generated in the eutectoid ferrite may hinder the complete annihilation of dislocations at the interface ${ }^{[29]}$, and the dislocations at the interface also moved into inside the eutectoid ferrite.

When the shear strain increased to 0.84 (Fig. 13(d), Fig. 13(e)), and the misorientation between adjacent lamellar gradually increased, and some low angles changed to high angles in the direction parallel to rolling. Meanwhile, the low-angle boundary with low-energy was formed inside the eutectoid ferrite lamellar. Fang et al. observed by TEM that both ends of dislocation entanglement in eutectoid ferrite lamellars were located at the ferrite/cementite interface ${ }^{[30]}$, and the same phenomenon was observed in the literature ${ }^{[21]}$. The eutectoid ferrite lamellar was gradually divided and refined (Fig. 10(f)).

When the shear strain $y>0.84$ (Fig. 13(f-g)), the eutectoid ferrite underwent significant plastic deformation, and the interlamellar spacing decreased continuously (Fig. 6(a), Fig. 6(b)). Smaller dislocation walls or dislocation cells was formed in the newly formed eutectoid ferrite grains (Fig. 11(d)), and changed into HABs in the same mechanism. However, due to the difference in strength between the proeutectoid ferrite and pearlite ${ }^{[31]}$, the number of HABs in the proeutectoid ferrite was larger than that in the eutectoid ferrite under the same shear strain, which also leaded to the rapid decrease of dislocation density in the proeutectoid ferrite (Fig. 11(a-e)), while the increase in the overall dislocation density gradually slowed down and finally decreased (Fig. 12).

\subsection{Formation of ultra-fine grain}

Under the effect of a certain shear strain, the proeutectoid ferrite and eutectoid ferrite formed dislocation cells or dislocation walls, which changed into LABs. When the shear strain $y<0.21$ (Fig. 13(b-c)), LABs were first formed in the proeutectoid ferrite, and a small amount of them was changed into HABs, while only the dislocation density increased in the eutectoid ferrite. The two kinds of ferrites were initially divided and refined, but the degree of refinement of the proeutectoid ferrites was significantly greater than that of the eutectoid ferrites. When the shear strain was at $0.21 \leq y \leq 0.84$ (Fig. 13(d-e)), the number of HABs in the proeutectoid ferrite increased significantly, and the new grains were formed in the sub-grains after plastic deformation, and the grain size decreased and gradually formed equiaxed small grains (Fig. 5)). Due to the supporting role of cementite, the interlamellar spacing remains unchanged (Fig. 13(be)), LABs were formed inside the eutectoid ferrite lamellar, which caused the ferrite lamellar to be divided into bamboo-like.

As the shear strain increased to 1.692 (Fig. 13(f)), a large number of dislocations act at the eutectoid ferrite interface, and caused local shear deformation of the cementite phase ${ }^{[32]}$, and cementite at an angle to the rolling direction bent and deformed parallel to the rolling direction, and the interlamellar spacing was markedly reduced (Fig. 6(b)), two kinds of ferrite have undergone significant deformation. A few equiaxed grains in the proeutectoid ferrite were elongated to form bamboo-like grains, while the bamboo-like grains were continuously divided by LABs (Fig. 6(e)). The number of LABs inside the eutectoid ferrite lamellar have increased significantly, and a small amount of LABs have been changed into HABs, and the eutectoid ferrite continued to be divided and refined. Cementite did not play a supporting role for eutectoid ferrite, but formed a squeezing effect, reducing the average free path of 
dislocation, resulting in a great increase in dislocation productivity, increasing dislocation density (Fig. 11(d), Fig. 12).

When the shear strain was at $1.692<\gamma<3.223(\mathrm{Fig} .13(\mathrm{~g}))$, the pearlite deformation was more severe, and the cementite was fractured and fragmented. The interaction between the dislocation and the cementite caused partial cementite to dissolve, while the undissolved cementite was still in the eutectoid ferrite boundary. Two kinds of ferrite were refined into bamboo-like grains by the above mechanism. Some carbon atoms were dissolved in eutectoid ferrite under the action of deformation driving force, so that the carbon atoms in eutectoid ferrite reached supersaturation ${ }^{[33]}$ and promoted the refinement of ferrite. Therefore, compared with the proeutectoid ferrite, eutectoid ferrite refinement was more serious. The proeutectoid ferrite grains were compressed in the normal direction and elongated in the rolling direction, and the size was further reduced. As the shear strain increase, and the changes of two kinds of ferrite were repeated in the way of "elongation-bamboo-like refinement-elongation-refinement", so that the grain size was continuously reduced, and the difference between the two kinds of ferrite continued to decrease, and the dislocation density in the grain decreased rapidly. When the dislocation nucleation rate and the annihilation rate reached a balance, the cementite particles did not continue to dissolve and become smaller, the ferrite grain size was not refined, and the size of ferrite and cementite reached a stable state. When the shear strain was 3.314 (Fig. 13(h)), the proeutectoid ferrite and eutectoid ferrite were completely mixed into the same morphology, which was difficult to distinguish. As the strain further increased, ultrafine ferrite grain with an average grain size of $110 \mathrm{~nm}$ was formed, and the high-angle boundaries distribution became more and more uniform, mainly distributed at 10-62 (Fig. 10(f)).

\section{Conclusions}

The wear experiment of D2 wheel steel was carried out on a double-disc rolling friction and wear test machine in a rolling condition. The refining process and mechanism of proeutectoid ferrite and eutectoid ferrite were analyzed by EBSD method, and the conclusions are as follows:

1. With the increase of the shear strain $(y<0.207)$, the dislocation density in the proeutectoid ferrite increased continuously, and the dislocation cells formed were uniformly distributed in the grains. Subsequently, the dislocation cell boundaries were changed into low-angle boundaries, and then gradually changed into the high-angle boundaries, and the average grain size was refined from the original $8 \mu \mathrm{m}$ to $710 \mathrm{~nm}$. When the shear strain was at $0.21 \leq \gamma \leq 0.84$, the grains were gradually refined into small equiaxed grain. When the shear strain $y>0.84$, the grains were repeatedly refined many times by the way of "elongation-bamboo like refinement-elongation".

2. When the shear strain was at $0.21 \leq y \leq 0.84$, dislocation piled up occurred at the ferrite side of the interface of eutectoid ferrite/cementite, and the spatial misorientation between adjacent two eutectoid ferrites increased gradually, meanwhile, the ferrite was divided into bamboo-like by lowangle boundaries. When the shear strain $y>0.84$, the number of high-angle boundaries inside the eutectoid ferrite lamellar increased, and it was refined into bamboo-like grains, which were then 
elongated and refined, and the grain size difference between proeutectoid ferrite and eutectoid ferrite decreased.

3. When the shear strain was at $3.314 \leq y \leq 3.45$, the fragmentation and dissolution of the cementite become more serious, and the undissolved cementite exists in the form of particles. The two kinds of ferrite were completely mixed into the same morphology, which was difficult to distinguish. The ferrite grains almost all changed to high-angle boundaries, and the dislocation density was dramatically reduced, formed ultra-fine equiaxed grains about $110 \mathrm{~nm}$.

\section{Declarations}

\section{Acknowledgments}

The project was supported by the National Basic Research Program of China (973) (2015CB654802).

\section{Declaration of interests}

The authors declared that they have no conflicts of interest to this work.

\section{References}

1. Donzella, G., Faccoli, M., Ghidini, A., Mazzu, A., Roberti, R.: The competitive role of wear and RCF in a rail steel. Eng. Fract. Mech. 72(2), 287-308 (2005)

2. Knupp, G.G., Chidley, W.H., et al.: A review of the manufacture, processing, and use of rail steels in North America-A report of AISI Technical Subcommittee on Rails and Accessories. In: Stone, D.H., Knupp, G.G. (eds.) Rail steels-developments, processing and use, pp. 7-20. ASTM, Philadelphia (1976)

3. Stone, D.H., Steel, R.K.: The effect of mechanical properties upon the performance of railroad rails. In: Stone, D.H., Knupp, G.G. (eds.) Rail steels-developments, processing and use, pp. 21-43. ASTM, Philadelphia (1976)

4. Kumar, A., Saxena, A.K., Kirchlechner, C., Herbig, M., Brinkmann, S., Petrov, R.H., Sietsma, J.: In situ study on fracture behaviour of white etching layers formed on rails, Acta Mater. https://doi.org/10.1016/j.actamat.2019.08.060

5. Zhao, X.N., Chen, G.X., Lv, J.Z., Zhang, S., Wu, B.W., Zhu, Q., Study on the mechanism for the wheel polygonal wear of high-speed trains in terms of the frictional self-excited vibration theory, wear. 426427: (2019)1820-1827

6. Tunna1, J., Sinclair, J., Perez, J., A review of wheel wear and rolling contact fatigue, Proc. Inst. Mech. Eng. Part F: J. Rail Rapid Transit 221: (2007) 271-289

7. Mazzù, A., Petrogalli, C., Faccoli, M.: An integrated model for competitive damage mechanisms assessment in railway wheel steels. Wear. 322, 181-191 (2015) 
8. Pyzalla, A., Wang, L., Wild, E., Wroblewski, T.: Changes in microstructure, texture and residual stresses on the surface of a rail resulting from friction and wear. Wear. 251, 901-907 (2001)

9. Pan, R., Ren, R.M., Chen, C.H., Zhao, X.J.: Formation of nanocrystalline structure in pearlitic steels by dry sliding wear, Mater. Charact. (2017), doi:10.1016/j.matchar.2017.05.031

10. Languillaume, J., Kapelski, G., Baudelet, B.: Cementite dissolution in heavily cold drawn pearlitic steel wires. Acta Mater 45, 1201-1212 (1997)

11. Gridnev, V.N., Nemoshkalenko, V.V., Meshkov, Y.Y., Gavrilyuk, V.G., Prokopenko, V.G., Razumov, O.N.: Mössbauer effect in deformed Fe-C alloys. Physica Status Solidi 31(1), 201-210 (1975)

12. Gavriljuk, V.G.: Effect of interlamellar spacing on cementite dissolution during wire drawing of pearlitic steel wires. Scr Mater 45, 1469-1472 (2001)

13. Hu, C., Zhang, C., Liu, W.B., Li, Q.H., Chen, H., Yang, Z.G., Weng, Y.Q.: Microstructure evolution of a hypoeutectoid pearlite steel under rolling-sliding contact loading. Mater. Sci. Eng. A. 655, 50-59 (2016)

14. Hu, Y., Su, C.R., Guo, L.C., Liu, Q.Y., Guo, J., Zhou, Z.R., Wang, W.J.: Effect of rolling direction on microstructure evolution of CL60 wheel steel, Wear. 424-425 (2019) 203-215

15. Hua, J., Zhao, X.J., Liu, P.T., Su, C., Ren, R.M.: Study on the mechanism for polygonisation formation of D2 wheel steel and its effect on microstructure and properties under rolling wear conditions, Wear, 450-451 (2020) 203261

16. Pan Rui, C., Chunhuan, R., Ruiming. A Method of Preparing SEM Specimen Including White Etching Layer: China, CN 105242075 A.2016-01-13.(In Chinese)

17. Durgaprasad, A., Giri, S., Lenka, S., Kundu, S., Mishra, S., Chandra, S., Doherty, R.D.: I.Samajdar, Defining a relationship between pearlite morphology and ferrite crystallographic orientation. Acta Mater 129, 278-289 (2017)

18. Heilmann, P., Rigney, D.A.: An energy-based model of friction and its application to coated systems,Wear, 1981, 72: 195-217

19. Ding, H.H., Fu, Z.K., Wang, W.J., Guo, J., Liu, Q.Y., Zhu, M.H.: Investigation on the effect of rotational speed on rolling wear and damage behaviors of wheel/rail materials, Wear. 330-331 (2015) 563570

20. Ding, H.H., He, C.G., Ma, L., Guo, J., Liu, Q.Y., Wang, W.J.: Wear mapping and transitions in wheel and rail materials under different contact pressure and sliding velocity conditions, Wear. 352-353 (2016) $1-8$

21. Zhang, X.D., Hansen, N., Godfrey, A., Huang, X.X.: Dislocation-based plasticity and strengthening mechanisms in sub-20nm lamellar structures in pearlitic steel wire, Acta Mater. 2016:S135964541630307X

22. Calcagnottok, M., Ponge, D., Demir, E., Raabe, D.: Orientation gradients and geometrically necessary dislocations in ultrafine grained dual phase steels studied by 2D and 3D EBSD. Mater. Sci. Eng. A. 527, 2738-2746 (2010) 
23. Liu, Q., Juul Jensen, D., Hansen, N.: Effect of grain orientation on deformation structure in cold-rolled polycrystalline aluminium. Acta Mater. 46, 5819-5838 (1998). doi:10.1016/S1359-6454(98)00229-8

24. Borchers, C., Kirchheim, R.: Cold-drawn pearlitic steel wires. Prog. Mater Sci. 82, 405-444 (2016)

25. Linz, M., Cihak-Bayr, U., Trausmuth, A., Scheriau, S., Künstner, D., Badisch, E.: EBSD study of earlydamaging phenomena in wheel-rail model test. Wear 342-343, 13-21 (2015)

26. Terashima, T., Tomota, Y., Isaka, M., Suzuki, T., Umemoto, M., Todaka, Y.: Strength and deformation behavior of bulky cementite synthesized by mechanical milling and plasma-sintering. Scr. Mater. 54(11), 1925-1929 (2006)

27. Wang, J., Misra, A.: An overview of interface-dominated deformation mechanisms in metallic multilayers. Curr. Opin. Solid State Mater. Sci. 15(1), 20-28 (2011)

28. Zhang, X., Godfrey, A., Hansen, N., Huang, X.: Hierarchical structures in cold drawn pearlitic steel wire. Acta Mater. 61, 4898-4909 (2013)

29. Liang, L.W., Wang, Y.J., Chen, Y., Wang, H.Y., Dai, L.H.: Dislocation nucleation and evolution at the ferrite-cementite interface under cyclic loadings. Acta Mater 186, 267-277 (2020)

30. Fang, F., Zhou, L.C., Hu, X.J., Zhou, X.F., Tu, Y.Y., Xie, Z.H., Jiang, J.Q., Microstructure and mechanical properties of cold-drawn pearlitic wires affect by inherited texture,Materials \& design. 2015, 79(aug.):60-67

31. Lu, X.: Foundation of Heat Treatment Engineering, China. Mechanical Industry Press, Beijing (2007). (In Chinese)

32. Ghaffarian, H., Taheri, A.K., Kang, K., Ryu, S.: Molecular dynamics simulation study on the effect of the loading direction on the deformation mechanism of pearlite. Multiscale Sci. Eng. 1(1), 47-55 (2019)

33. Li, Y.J., Raabe, D., Herbig, M., Choi, P.P., Goto, S., Kostka, A., Yarita, H., Borchers, C., Kirchheim, R.: Segregation Stabilizes Nanocrystalline Bulk Steel with Near Theoretical Strength. Phys. Rev. Lett. 113(10), 106104 (2014)

\section{Figures}




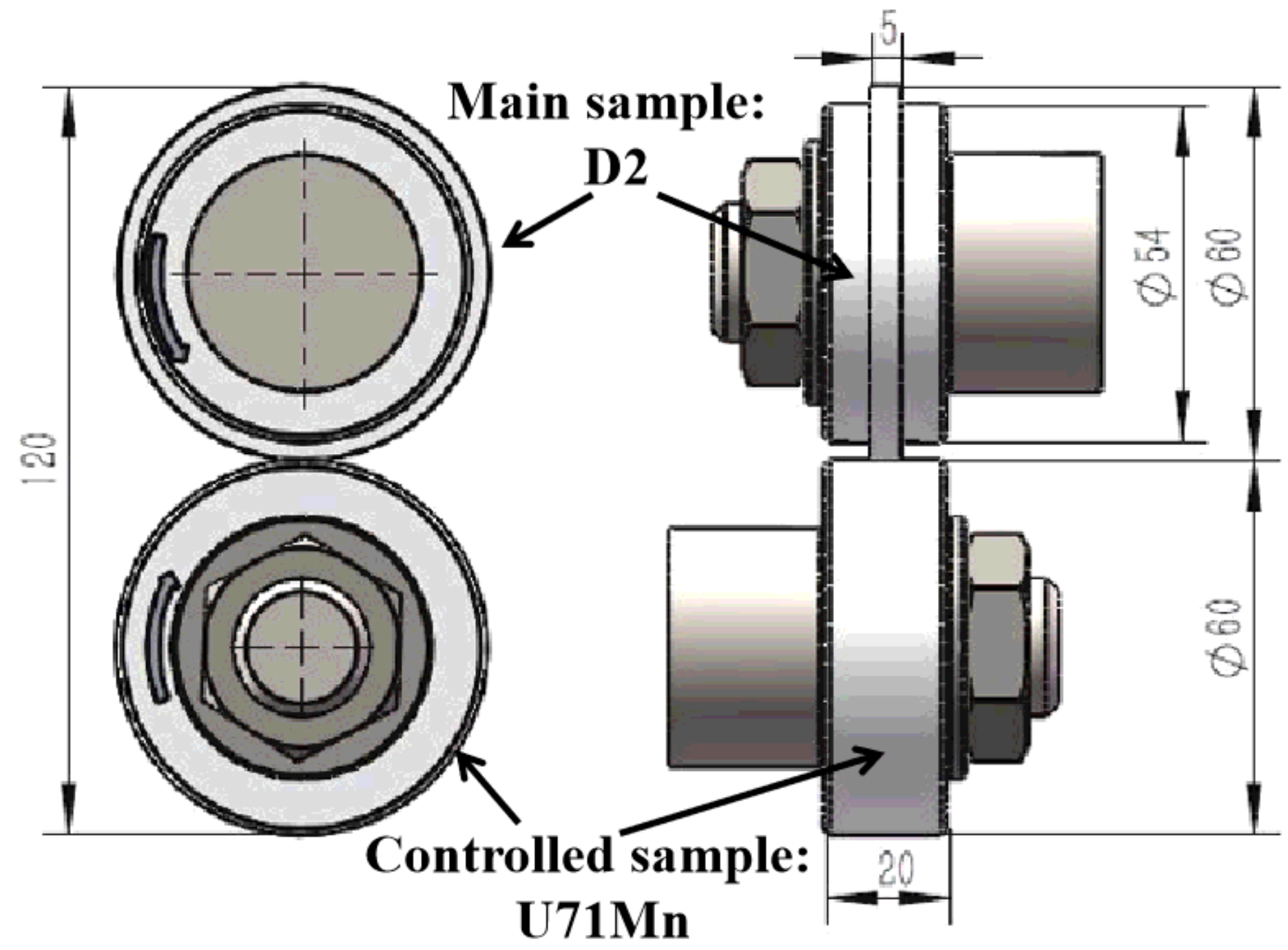

Figure 1

The contact mode and size diagram of the sample $(\mathrm{mm})$ 

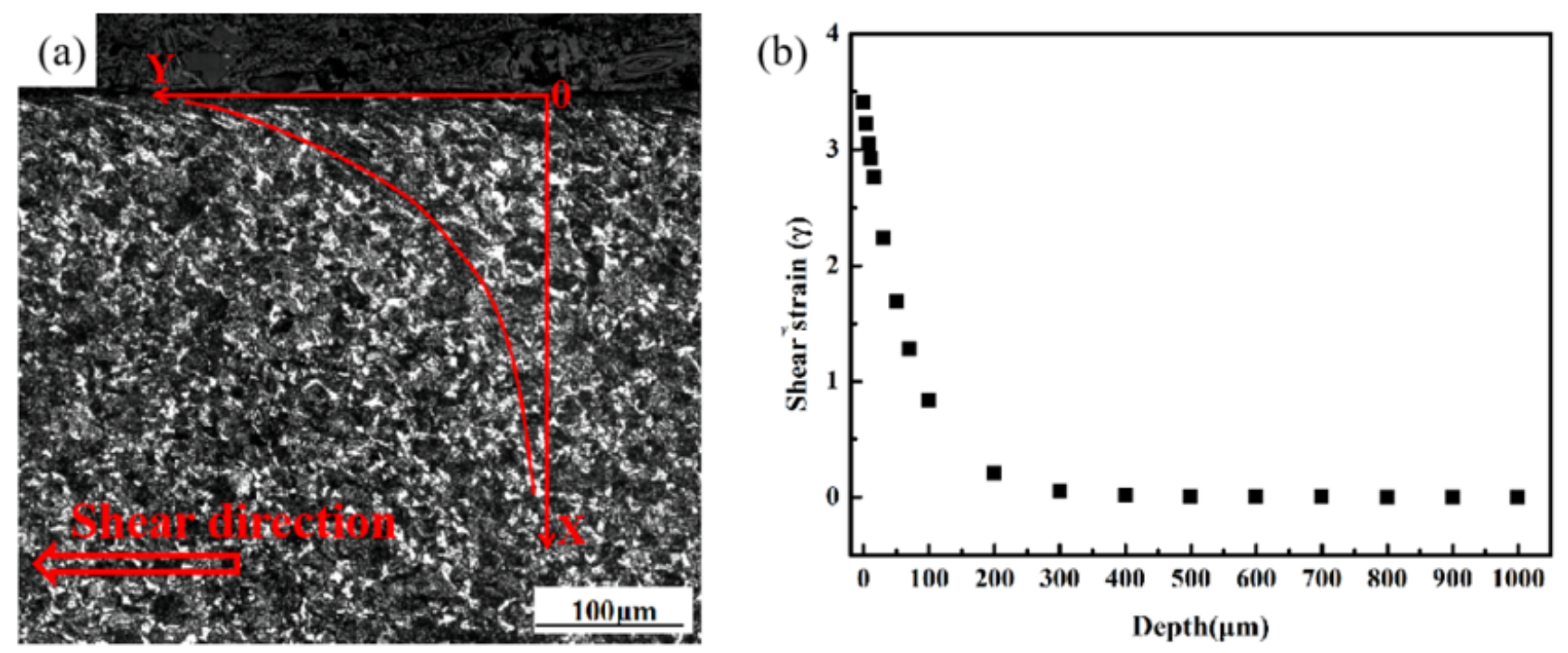

Figure 2

OM microstructure and shear strain (a) OM microstructure; (b) The relationship between the shear strain and the distance from the surface 

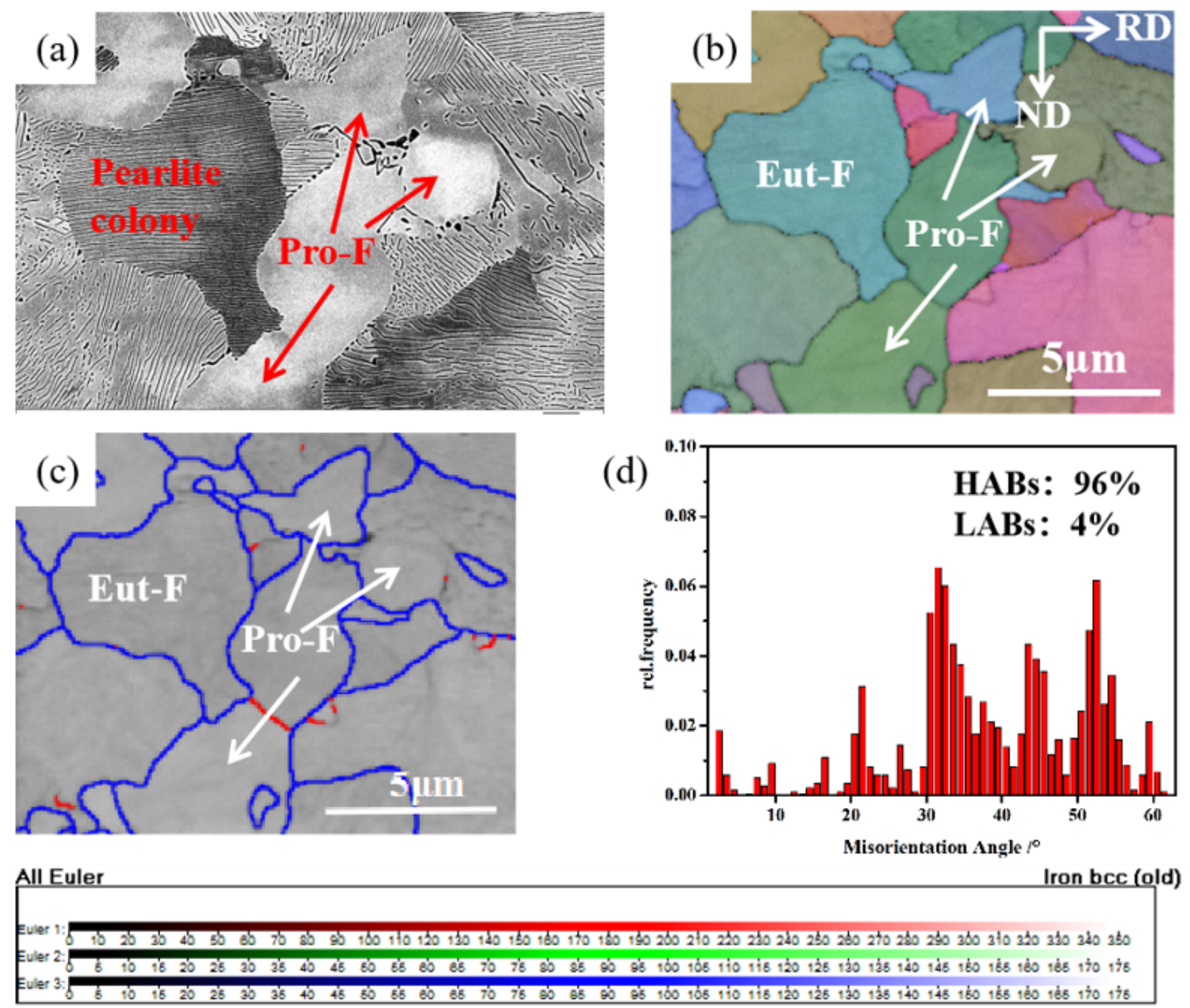

\section{Figure 3}

The original microstructure of D2 wheel steel (a) SEM picture; (b) the Euler angle map of (a); (c) the corresponding grain boundary map of (b); (d) the corresponding grain boundary misorientation distribution of (c). Note: The designations employed and the presentation of the material on this map do not imply the expression of any opinion whatsoever on the part of Research Square concerning the legal status of any country, territory, city or area or of its authorities, or concerning the delimitation of its frontiers or boundaries. This map has been provided by the authors. 

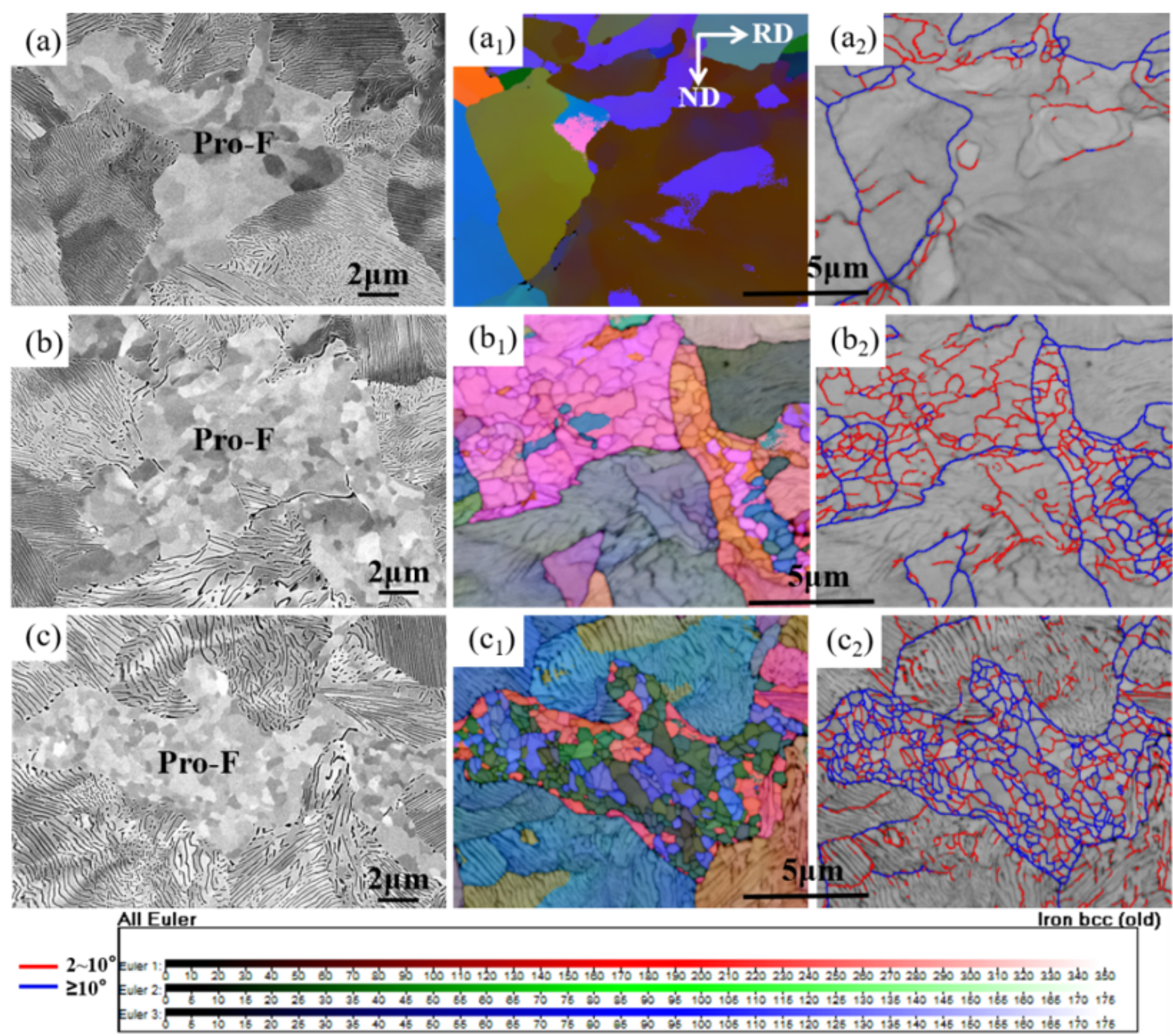

Figure 4

The microstructure at $400 \mu \mathrm{m}(\mathrm{\gamma}=0.012), 300 \mu \mathrm{m}(\mathrm{\gamma}=0.051)$ and $200 \mu \mathrm{m}(\mathrm{\gamma}=0.21)$ (a), (b)and (c) SEM picture; (a1), (b1)and (c1) the Euler angle map corresponding to EBSD; (a2),(b2) and (c2) the corresponding grain boundary map of (a1), (b1)and (c1), respectively. Note: The designations employed and the presentation of the material on this map do not imply the expression of any opinion whatsoever on the part of Research Square concerning the legal status of any country, territory, city or area or of its authorities, or concerning the delimitation of its frontiers or boundaries. This map has been provided by the authors. 

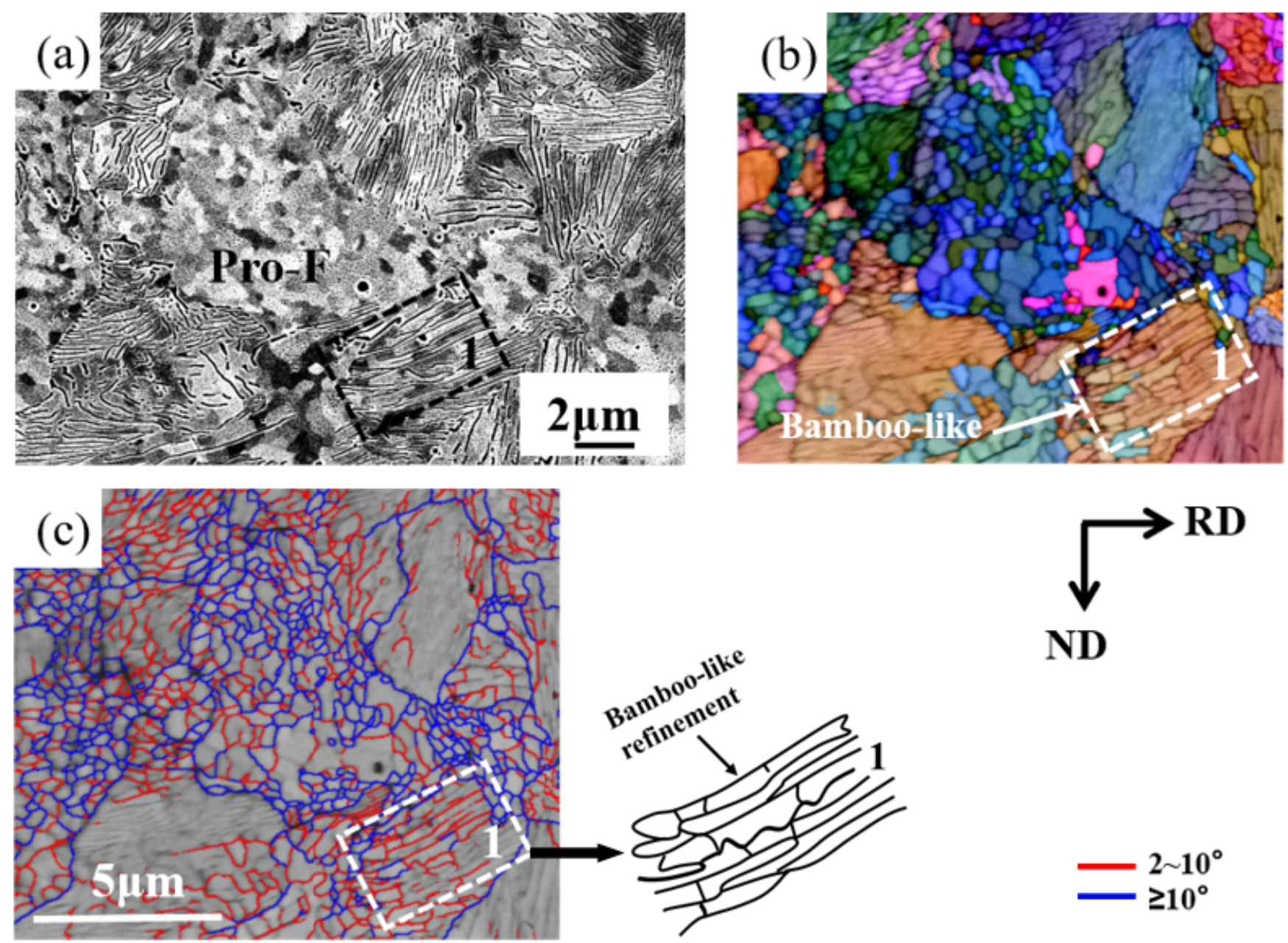

All Euler

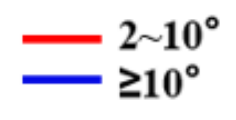

Euler $1: 5$
Euler 2:8
Euler 3:5
ure 5

The microstructure at $100 \mu \mathrm{m}(\mathrm{\gamma}=0.84)$ from the surface (a) SEM picture; (b) the Euler angle map of (a); (c) the corresponding grain boundary map of (b). Note: The designations employed and the presentation of the material on this map do not imply the expression of any opinion whatsoever on the part of Research Square concerning the legal status of any country, territory, city or area or of its authorities, or concerning the delimitation of its frontiers or boundaries. This map has been provided by the authors. 

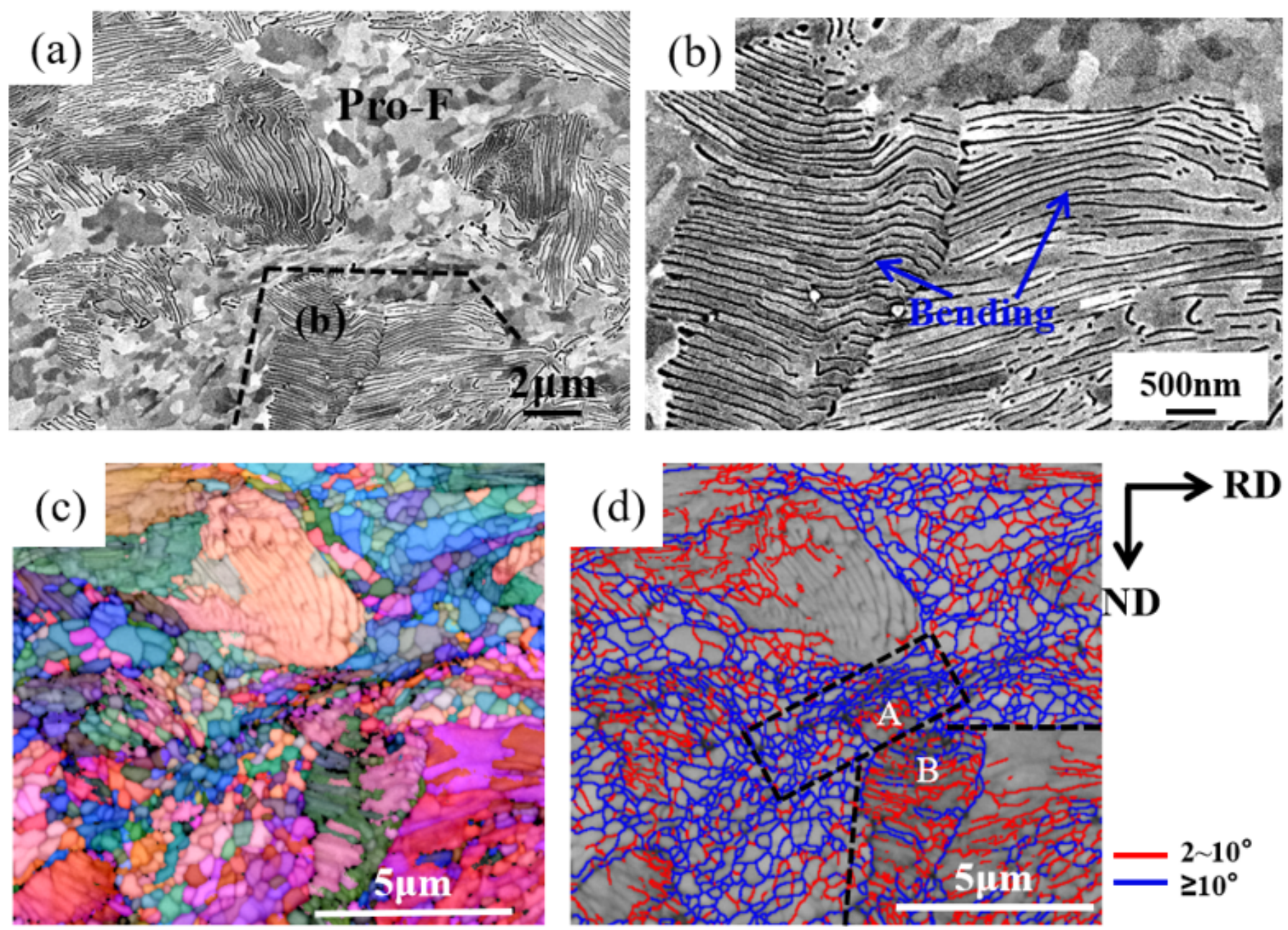

All Euler

Iron bcc (old)

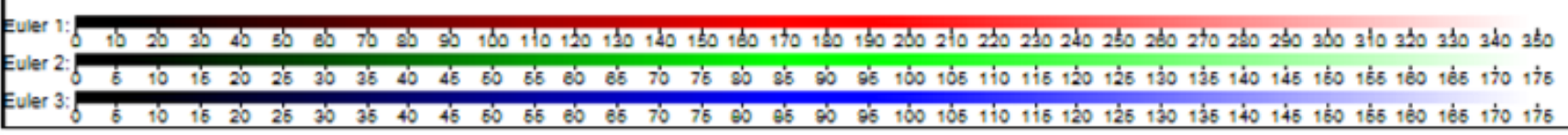

\section{Figure 6}

The microstructure at $50 \mu \mathrm{m}(\mathrm{\gamma}=1.692)$ from the surface (a) SEM picture; (b) the local SEM image of (a); (c) the Euler angle map of (a); (d) the corresponding grain boundary map of (c). Note: The designations employed and the presentation of the material on this map do not imply the expression of any opinion whatsoever on the part of Research Square concerning the legal status of any country, territory, city or area or of its authorities, or concerning the delimitation of its frontiers or boundaries. This map has been provided by the authors. 


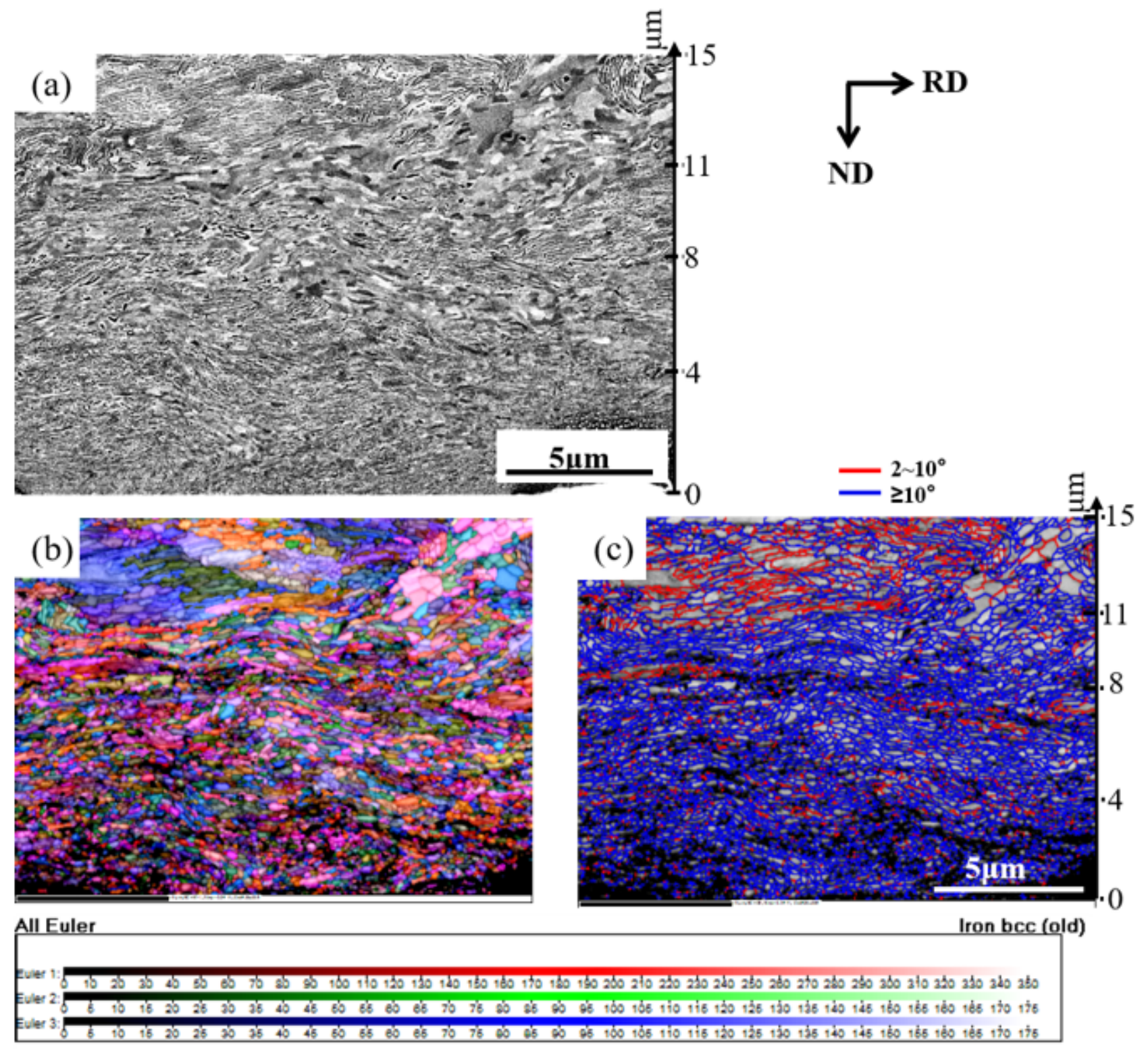

Figure 7

Microstructure change within 15-0 $\mu \mathrm{m}$ ( $\mathrm{y}=2.763-3.45)$. (a) SEM picture; (b) the local SEM image of (a); (c) the Euler angle map of (a); (d) the corresponding grain boundary map of (c). Note: The designations employed and the presentation of the material on this map do not imply the expression of any opinion whatsoever on the part of Research Square concerning the legal status of any country, territory, city or area or of its authorities, or concerning the delimitation of its frontiers or boundaries. This map has been provided by the authors. 


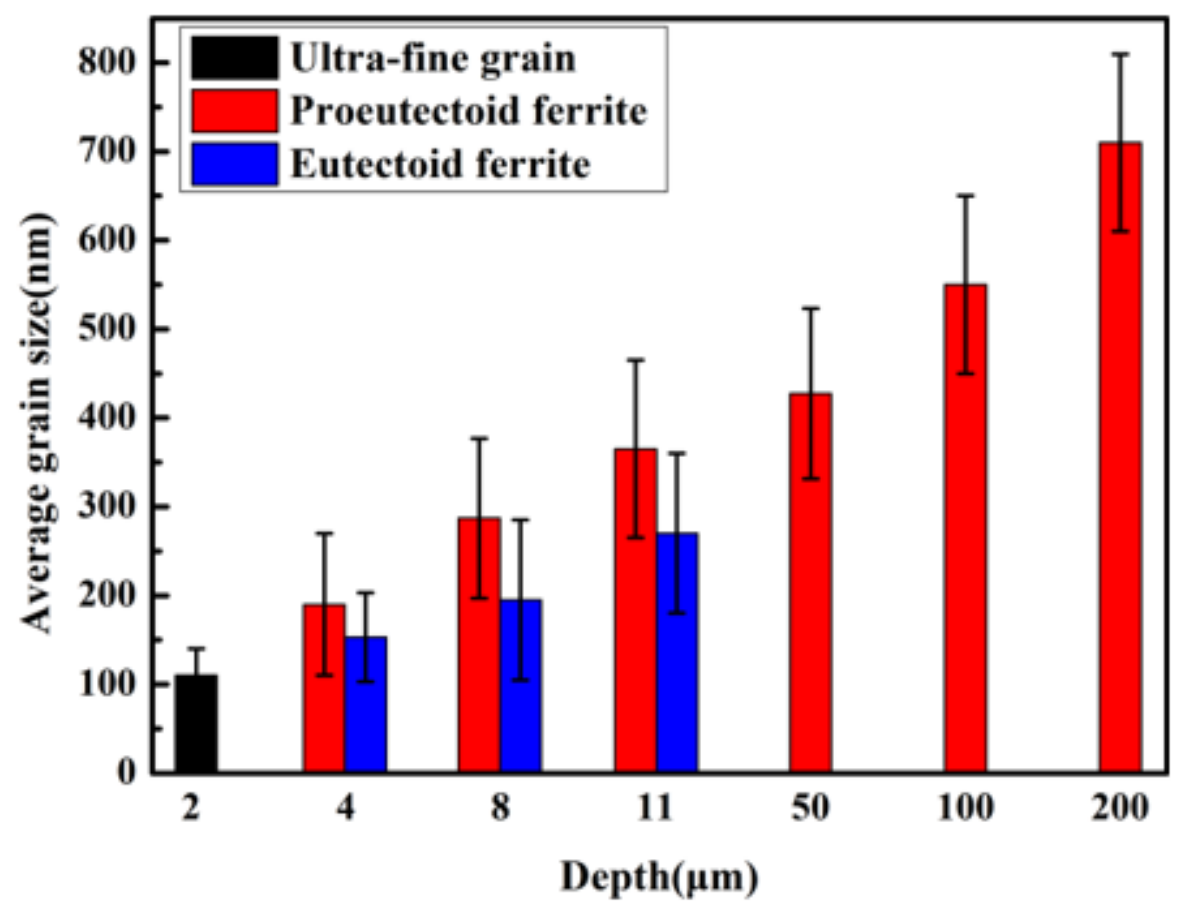

Figure 8

Changes in grain size

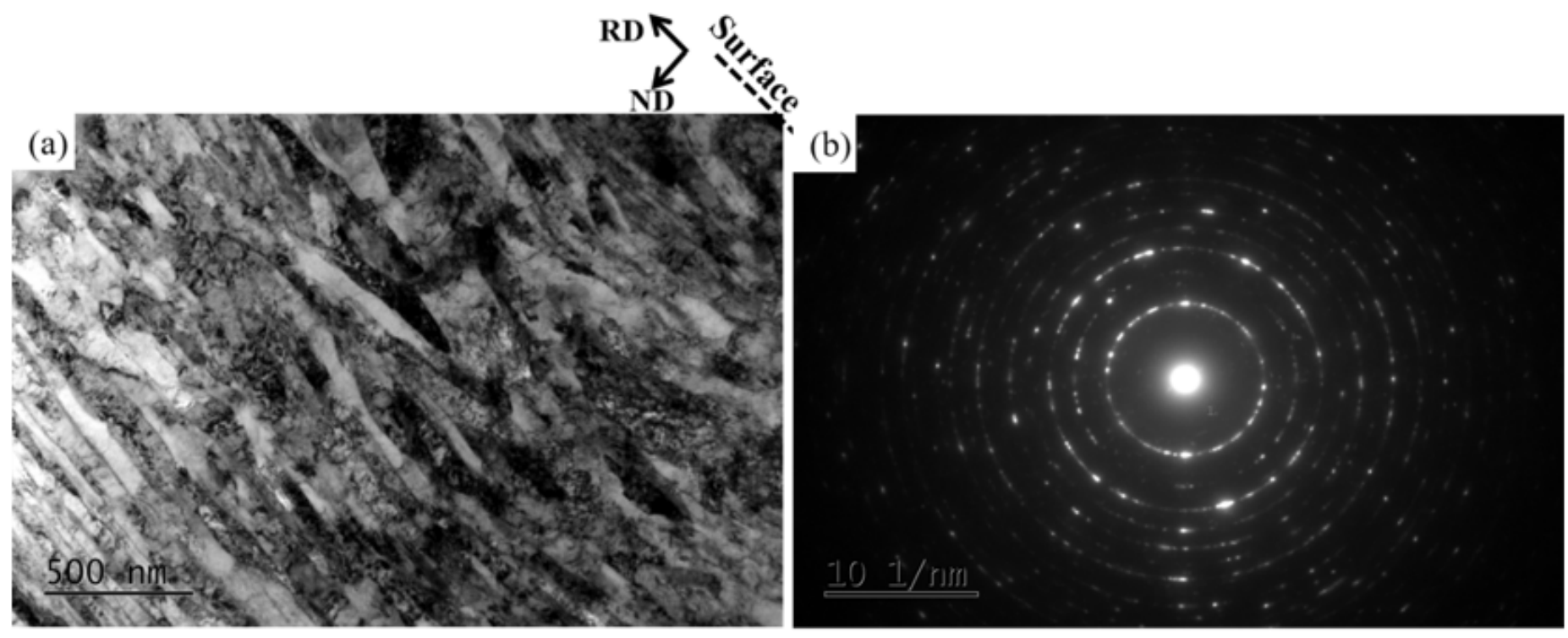

Figure 9

TEM images (a) Bright-field images; (b) selected-are electron diffraction. 

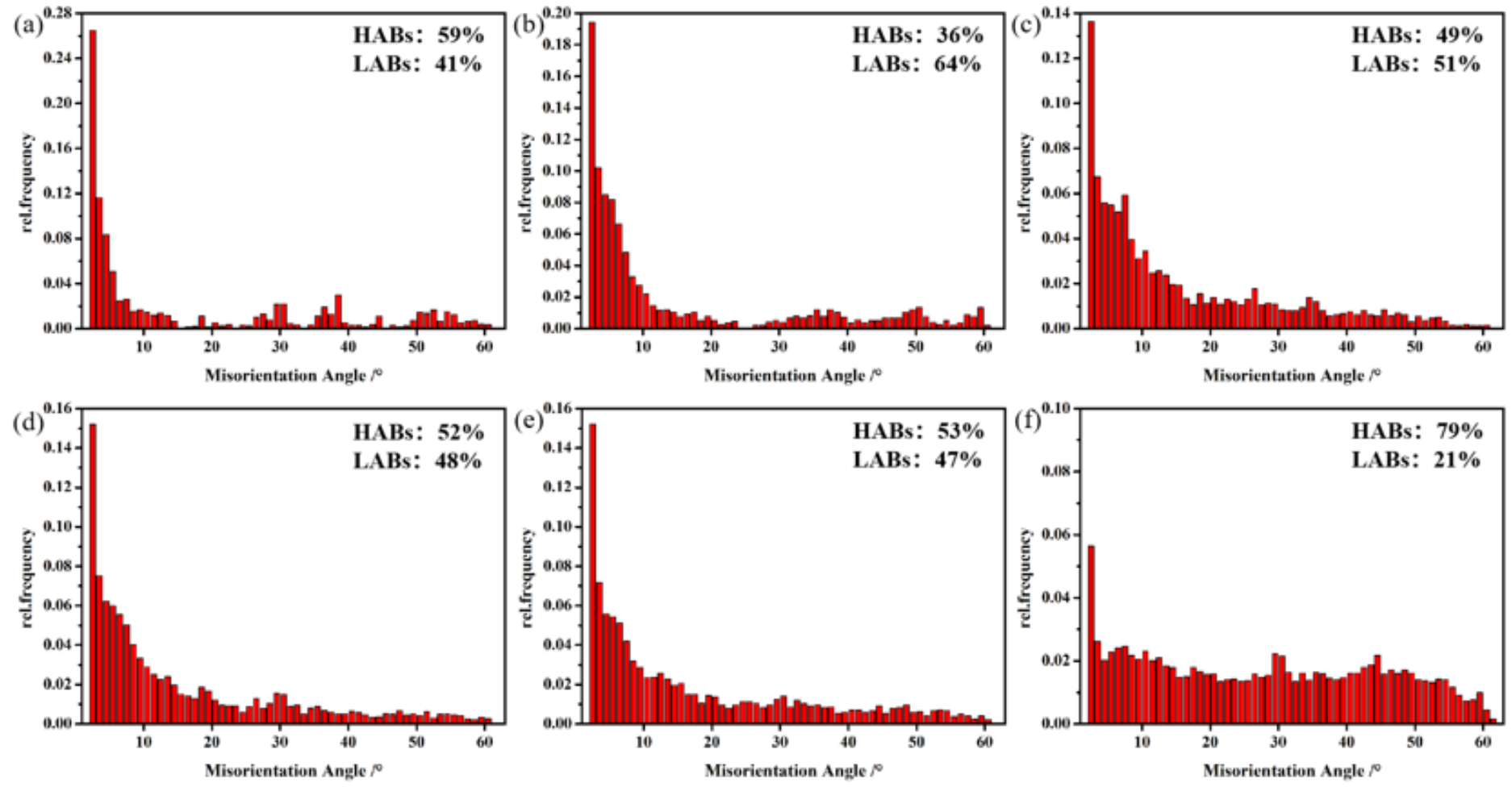

Figure 10

Misorientation angle distributions (a) $400 \mu \mathrm{m}(\mathrm{\gamma}=0.012)$; (b) $300 \mu \mathrm{m}(\mathrm{\gamma}=0.051)$; (c) $200 \mu \mathrm{m}(\mathrm{\gamma}=0.21)$; (d)100 $\mu \mathrm{m}(\mathrm{Y}=0.84) ;(\mathrm{e}) 50 \mu \mathrm{m}(\mathrm{\gamma}=1.692) ;$ (f) $15-0 \mu \mathrm{m}(2.763 \leq \mathrm{Y}<3.45)$. 

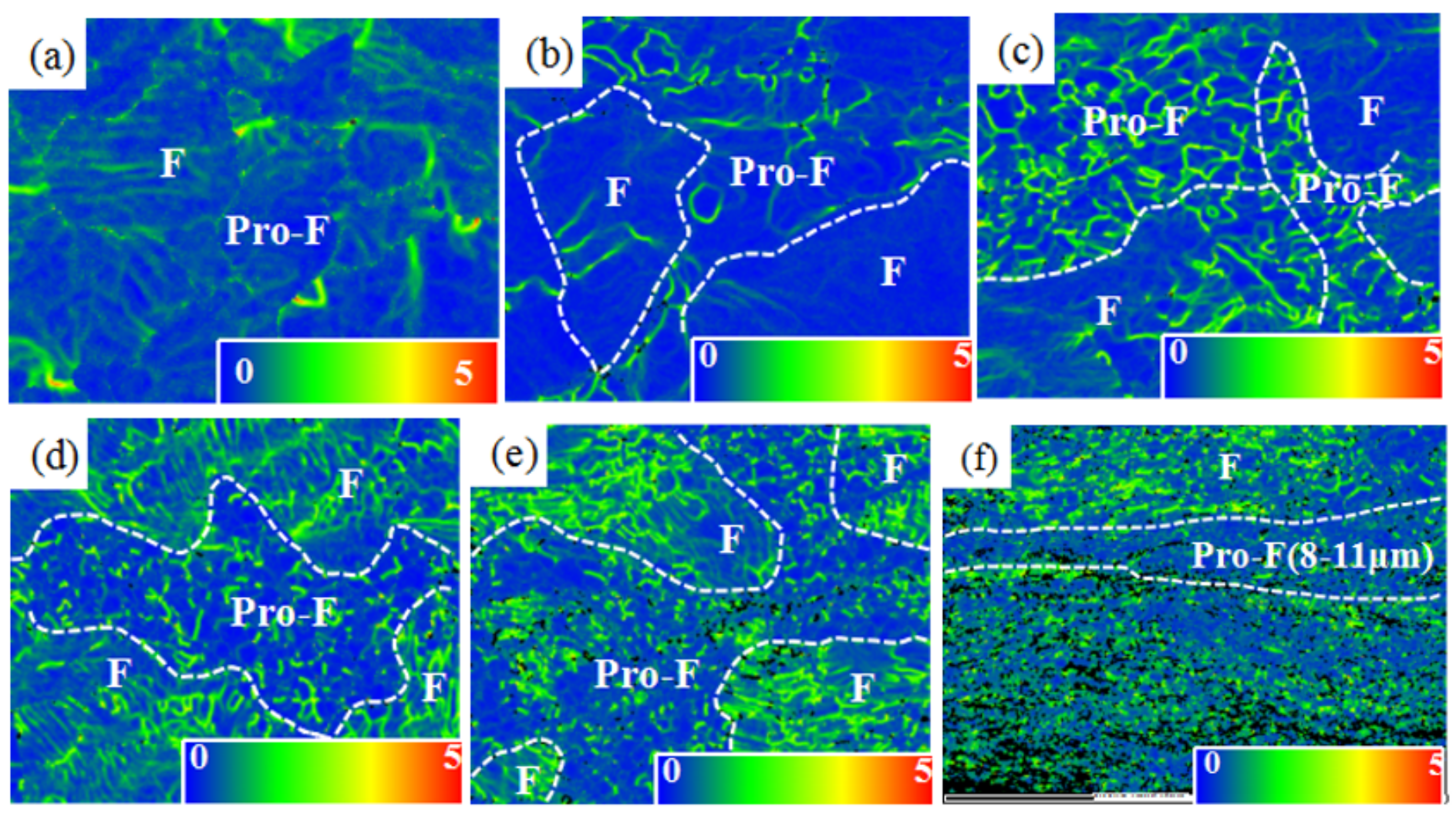

\section{Figure 11}

Local misorientation at different distances from the surface (a) $800 \mu \mathrm{m}(\mathrm{\gamma}=0)$; (b) $400 \mu \mathrm{m}$ ( $\mathrm{\gamma}=0.012)$; (c)

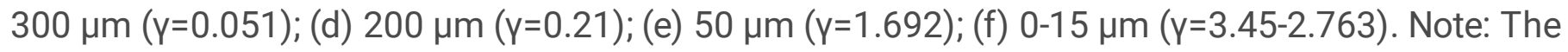
designations employed and the presentation of the material on this map do not imply the expression of any opinion whatsoever on the part of Research Square concerning the legal status of any country, territory, city or area or of its authorities, or concerning the delimitation of its frontiers or boundaries. This map has been provided by the authors. 


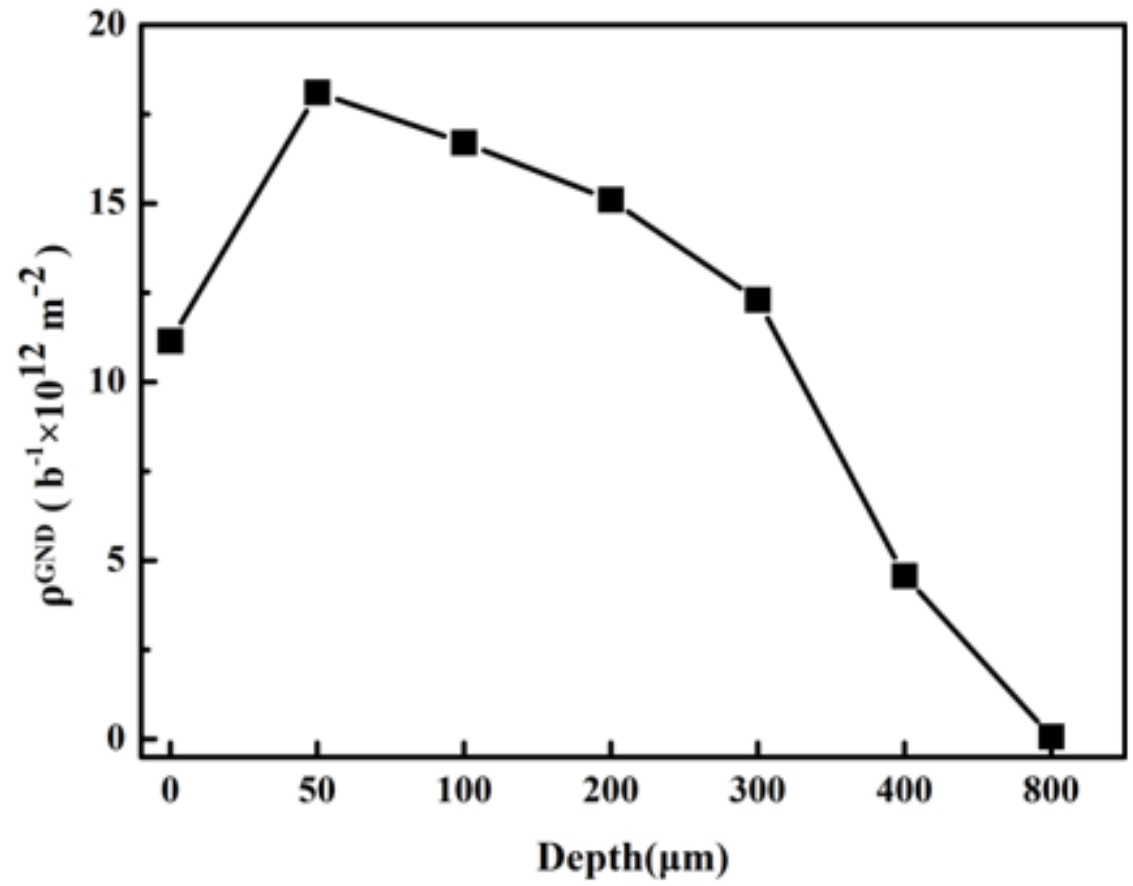

Figure 12

The dislocation density changes 


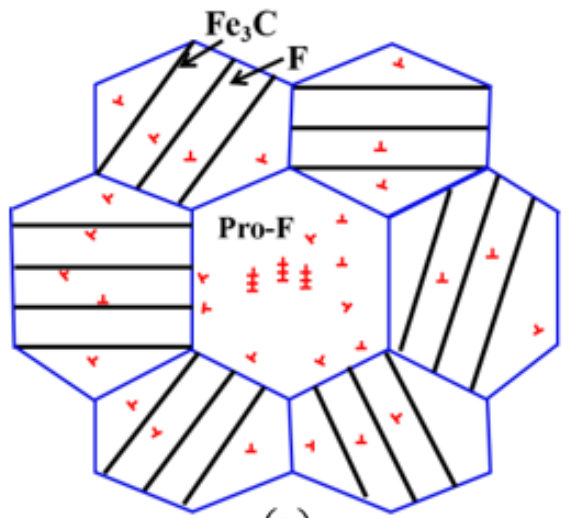

(a)

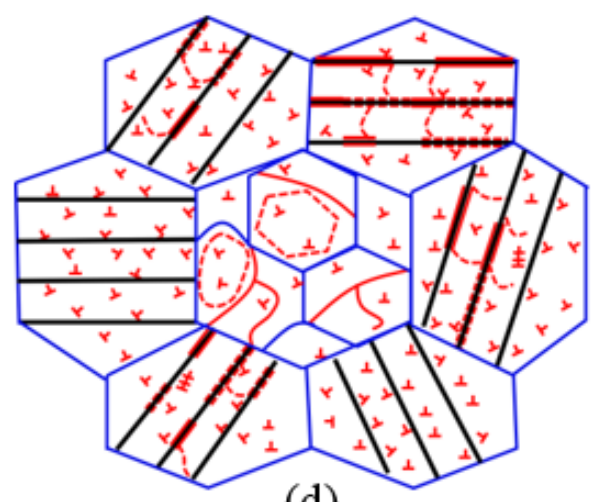

(d)

Pro-F

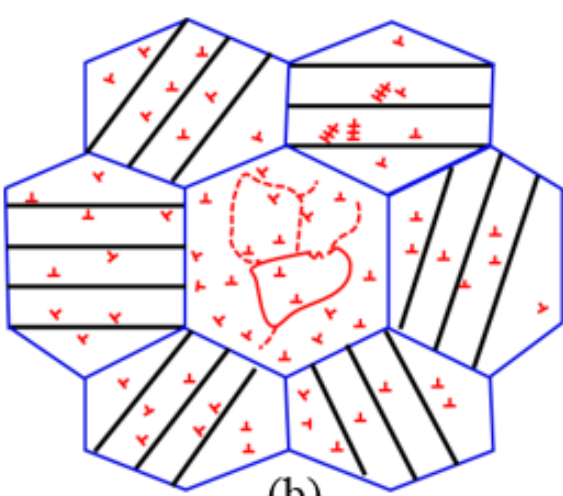

(b)

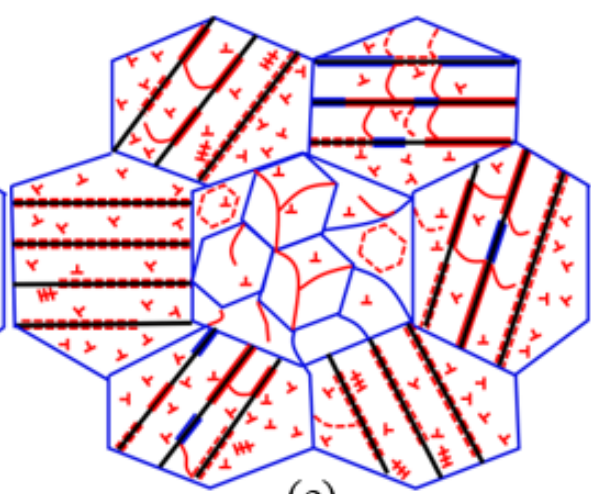

(e)

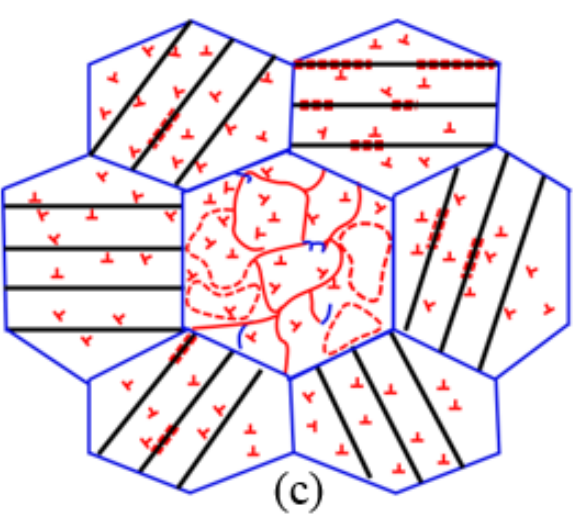

(c)

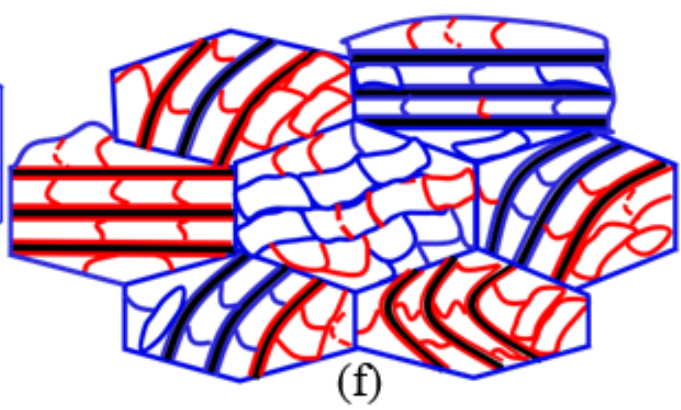

(f)

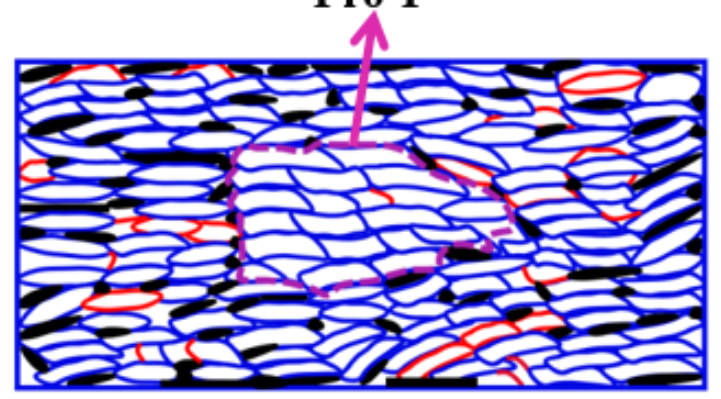

(g)

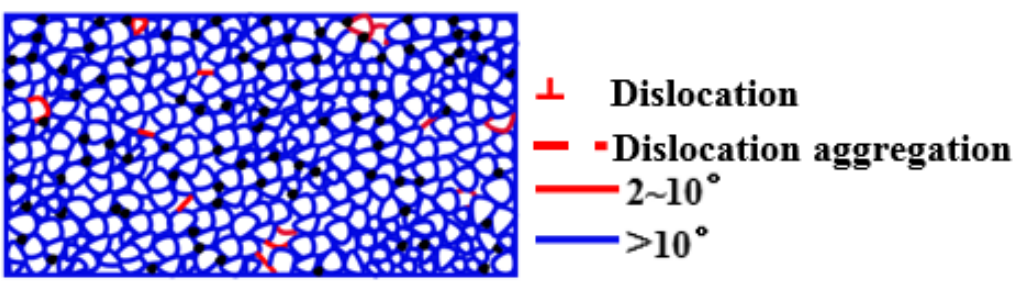

(h)

Figure 13

Microstructure evolution diagram under different shear strains (a) $y=0$; (b) $y=0.012 ;$ (c) $Y=0.051$; (d) $\mathrm{Y}=0.21 ;(\mathrm{e}) \mathrm{Y}=0.84 ;$ (f) $\mathrm{y}=1.692 ;(\mathrm{g}) \mathrm{y}=2.763 ;$ (h) $\mathrm{y}=3.314$. 